\title{
RT-PCR Based Detection of Rupestris stem pitting associated virus Within Field-Grown Grapevines Throughout the Year
}

\author{
Sandra Stewart and Annette Nassuth, Department of Botany, University of Guelph, ON, Canada, N1G 2W1
}

\begin{abstract}
Stewart, S., and Nassuth, A. 2001. RT-PCR based detection of Rupestris stem pitting associated virus within field-grown grapevines throughout the year. Plant Dis. 85:617-620.

The presence of Rupestris stem pitting associated virus (RSPaV) can go unnoticed since symptoms appear only if additional viruses are present. Detection by reverse transcriptionpolymerase chain reaction (RT-PCR) is possible; however, this assay could be unreliable if the tissue that is being tested has detection-interfering compounds, or if the virus has a low titer. This paper reports on (i) use of a recently developed extraction method and internal control to determine which tissues from field-grown grapevines yield extracts that are reliable for virus detection by RT-PCR, and (ii) a survey for RSPaV of different tissues from the Vitis vinifera varieties Riesling, Chardonnay, Cabernet Franc, Merlot, Sauvignon Blanc, Pinot Noir, and Gamay, as well as from the rootstocks 3309 and Riparia, which were harvested in Ontario, Canada, at different times of the year. Amplifiable extracts were obtained from virtually all bud, shoot tip, seed, and cane samples tested. Detectable amounts of RSPaV were generally found in all tissues of infected plants except young buds collected in the summer. A combination of three single buds from dormant canes, less time-consuming than the preparation of cane shavings, was a reliable source for RSPaV detection.
\end{abstract}

Additional keywords: Rupestris stem pitting, virus distribution

Rupestris stem pitting, corky bark, Kober stem grooving, and LN33 stem grooving, collectively referred to as Rugose wood, are a group of grafttransmitted diseases of grapevines characterized by distortions of the woody trunk which can be found in all viticultural regions of the world (5). These diseases are responsible for graft incompatibility problems, delayed budburst, severe decline, and even death of vines $(2,8)$. A combination of viruses and possibly phytoplasmas is thought to be the causative agent for the Rugose wood diseases (2). However, exactly which combinations of viruses and phytoplasmas are present in diseased plants, and which combinations of those pathogens cause which symptoms still need to be determined.

Rupestris stem pitting (RSP) appears to be the most widespread disease of the Rugose wood complex (10). Rupestris stem pitting associated virus (RSPaV), a foveavirus, is consistently detected in RSPinfected grapevines (9,22); however, $\mathrm{RSPaV}$ alone generally does not produce any symptoms and has no major impact on grapevine growth and yield $(2,15)$. The presence of another virus, such as Grape-

Corresponding author: Annette Nassuth

E-mail: anassuth@uoguelph.ca

Accepted for publication 15 February 2001.

Publication no. D-2001-0326-02R

(C) 2001 The American Phytopathological Society vine virus A (GVA), Grapevine fleck virus, or Grapevine leafroll associated virus-1, in addition to RSPaV, is required for Rugose wood-type symptoms to occur (2). These viruses can be transmitted from infected vines to an $\mathrm{RSPaV}$-infected vine via grafting $(2,8)$ or, at least for GVA, via the vine mealybug Planococcus ficus $(3,11)$. This means that cultivating symptomless but $\mathrm{RSPaV}$-infected vines carries a risk for the development of RSP, and it is therefore of interest to know if a vine contains RSPaV.

The presence of RSPaV can be determined by reverse transcription-polymerase chain reaction (RT-PCR) using primers based on its genomic sequence $(9,22)$ with apparent greater reliability than biological indexing on St. George (9). It is not known if the RT-PCR assay is reliable for all tissues and at all times of the year. Grapevines contain high amounts of compounds such as phenolics and polysaccharides, believed to interfere with RT-PCR $(11,16,17,21)$, and it is likely that these amounts differ among different tissues at different times of the year. Also, several grapevine viruses appear to have an irregular distribution and/or low virus titer at certain times of the year $(11-13,17,19,20)$, and such may also be the case for RSPaV. As a result, it is possible that its presence is not detected even though a plant is infected.

Several methods have been developed in an attempt to deal with inhibitors of RTPCR assays $(7,11,18)$. We reported on an improved RNA extraction method to minimize inhibitors of reverse transcriptase and Taq polymerase, as well as controls that can identify plant extracts that contain such inhibitors and thus cannot be amplified by RT-PCR (14). In this study, we use the extraction method and control to survey extracts from grapevine tissues harvested from RSPaV-infected plants at different times of the year. Tissues shown to be amplifiable are tested for the presence of virus using a one-step RT-PCR assay, to determine its distribution.

\section{MATERIALS AND METHODS}

Plant material. RSPaV-infected samples came from six plants each of the Vitis vinifera varieties Riesling, Chardonnay, Cabernet Franc, Merlot, Sauvignon Blanc, Pinot Noir, and Gamay, as well as from the rootstocks 3309 and Riparia growing in fields in Niagara Peninsula, Ontario, Canada.

Buds, shoot tips, seeds, or cane samples were collected at different times in 1999 from six infected but symptomless plants of each variety, immediately put on ice for transport, and then stored at $-80^{\circ} \mathrm{C}$ until they were extracted. Spring samples consisted of single buds from stages $\mathrm{C}$ (opening bud), D (leaf emergence), E (two to three leaves unfolded), and/or F (inflorescences visible), and the last two nodes from stages $\mathrm{G}$ (inflorescences separated) or $\mathrm{H}$ (flowers separated) (stages according to M. Baggiolini [1]). The spring stages collected from each plant depended on what stages were available at the collection date. Summer samples consisted of single buds from woody canes, single buds from green canes, and single shoot tips. Fall samples consisted of three or more seeds from one berry. The rootstocks Riparia and 3309 do not produce any seed, hence none were collected. Prior to storage at $-80^{\circ} \mathrm{C}$, seeds were cleaned with water to remove pulp. Some seeds were additionally treated with a $3.5 \%$ sodium hypochlorite solution for 5 min and then rinsed in water for $5 \mathrm{~min}$. Winter samples were cane shavings and a single bud from each of three dormant canes. Cane shavings were obtained using a mechanical pencil sharpener (4).

Preparation of total RNA extract. Total RNA was extracted from samples according to a procedure modified from MacKenzie et al. (7), as described previously (14). Briefly, approximately $0.5 \mathrm{~g}$ of tissue was placed in a sample bag (Agdia Inc., Elkhart, IN) with $5 \mathrm{ml}$ of lysis buffer composed of $4 \mathrm{M}$ guanidium isothiocyanate, $0.2 \mathrm{M}$ sodium acetate, $\mathrm{pH} 5.0,25$ $\mathrm{mM}$ EDTA, 6\% PVP-40, and $1 \%$ 2- 
mercaptoethanol (added just prior to use), and homogenized with a hand-held homogenizer (BIOREBA, South Bend, IN). Single buds, some weighing as little as $0.009 \mathrm{~g}$, were extracted with a minimum of $2 \mathrm{ml}$ of lysis buffer. A 1-ml aliquot of the lysate was further processed with a Qiagen RNeasy plant extraction kit according to the instructions outlined by the manufacturer.

The obtained total RNA extracts $(100 \mu \mathrm{l})$ were stored in small aliquots at $-80^{\circ} \mathrm{C}$ (stock sample) and at $-20^{\circ} \mathrm{C}$ (working sample). Samples were thawed and refrozen no more than four times to minimize possible RNA degradation.

RT-PCR amplification. Target sequences were detected using target-specific primers (Table 1) in a single one-tube RTPCR reaction as described in Nassuth et al. (14). The RT-PCR mixture (final volume of $25 \mu \mathrm{l}$ ) contained $2.5 \mu \mathrm{l}$ total RNA extract, $10 \mathrm{mM}$ Tris- $\mathrm{HCl}, \mathrm{pH} 8.3,100 \mathrm{mM}$ $\mathrm{KCl}, 1.5 \mathrm{mM} \mathrm{MgCl} 2,200 \mu \mathrm{M} \mathrm{Mg}$ balanced dNTPs, $5 \mathrm{mM}$ dithiothreitol, $2 \%$ (wt/vol) sucrose, $0.1 \mathrm{mM}$ cresol red (Sigma, Oakville, ON), 0.1 units AMV RTase (reverse transcriptase, Boehringer Mannheim/
Roche, Laval, QC), 2 units Taq polymerase (Gibco/BRL, Burlington, ON, or Fermentas, Burlington, $\mathrm{ON}$ ), and $0.5 \mu \mathrm{M}$ (unless otherwise stated) of both the complementary and homologous primers specific for the target sequence(s). Amplification was carried out in a thermocycler (Perkin Elmer 2400 or MJ Research PTC100HB96V) using one 45 -min step at $54^{\circ} \mathrm{C}$ (reverse transcription), followed by 35 cycles of the following: $94^{\circ} \mathrm{C}$ for $30 \mathrm{~s}, 54^{\circ} \mathrm{C}$ for $45 \mathrm{~s}$, and $72^{\circ} \mathrm{C}$ for $60 \mathrm{~s}$, with a final elongation step at $72^{\circ} \mathrm{C}$ for $5 \mathrm{~min}$. Amplified products were stored at $4^{\circ} \mathrm{C}$ until analysis.

All combinations and concentrations of primer pairs used to detect the desired sequences were determined previously (14). Spring, summer, fall, and winter samples were first tested with a combination of primer pairs RubiscoL (control) and $\operatorname{RSPaV}(0.025 \mu \mathrm{M} / 0.5 \mu \mathrm{M})$ or malate dehydrogenase (MDH) (control), RSPaV and ArMV $(0.1 \mu \mathrm{M} / 0.5 \mu \mathrm{M} / 0.6 \mu \mathrm{M})$. Samples initially testing positive for the control(s) but negative for RSPaV were retested with only the RSPaV primer pair to verify the result. We tested all samples also with a

Table 1. DNA primers employed for reverse transcription-polymerase chain reaction (RT-PCR) amplification of grapevine viruses and control mRNA sequences

\begin{tabular}{|c|c|c|c|c|}
\hline $\begin{array}{l}\text { Target } \\
\text { sequence }\end{array}$ & Primer name & Primer sequence $\left(5^{\prime}\right.$ to $\left.3^{\prime}\right)$ & $\begin{array}{l}\text { Product } \\
\text { size (bp) }\end{array}$ & Ref. \\
\hline \multirow[t]{2}{*}{$\mathrm{MDH}^{\mathrm{a}}$} & MDH-H968 & GCATCTGTGGTTCTTGCAGG & 196 & 14 \\
\hline & MDH-C1163 & CCTTTGAGTCCACAAGCCAA & & \\
\hline \multirow{2}{*}{ RubiscoL } & RBCL-H535 & CTTTCCAAGGCCCGCCTCA & 171 & 14 \\
\hline & RBCL-C705 & CATCATCTTTGGTAAAATCAAGTCCA & & \\
\hline \multirow[t]{2}{*}{$\mathrm{RSPaV}^{\mathrm{b}}$} & RSP-H5638 & AGGGATTGGCTGTTAGATGTT & 355 & 6 \\
\hline & RSP-C5992 & CTTCAGGCAACCCCAAAAA & & \\
\hline \multirow[t]{2}{*}{ ArMV } & ARMV-H428 & GCGGCGGATTGGGAGTT & 440 & 6 \\
\hline & ARMV-C867 & CGATGGTAGGGGGAGCGTATT & & \\
\hline \multirow[t]{2}{*}{ GVA } & GVA-H7038 & AGGTCCACGTTTGCTAAG & 236 & 6 \\
\hline & GVA-C7273 & CATCGTCTGAGGTTTCTACTAT & & \\
\hline \multirow[t]{2}{*}{ GVB } & GVB-H6980 & GTGCTAAGAACGTCTTCACAGC & 460 & 6,11 \\
\hline & GVB-C7439 & ATCAGCAAACACGCTTGAACCG & & \\
\hline
\end{tabular}

a Controls: MDH, malate dehydrogenase, primer names based on Vitis vinifera MDH gb L34836; RubiscoL, large subunit of Ribulose biphosphate carboxylase oxygenase, primer names based on Rubisco sequence for Triticum (dbj D00206).

b Viruses: RSPaV, Rupestris stem pitting associated virus, primer names based on RSPaV gb AF026278; ArMV, Arabis mosaic virus, primer names based on ArMV emb X55460; GVA, Grapevine virus A, primer names based on GVA emb X75433; GVB, Grapevine virus B, primer names based on GVB emb X75448. combination of primer pairs GVA/GVB $(0.5 \mu \mathrm{M} / 0.5 \mu \mathrm{M})$.

Analysis of amplified product. Aliquots $(10 \mu \mathrm{l})$ of the PCR products were analyzed on a $1.5 \%$ agarose gel in $1 \times \mathrm{TBE}$ buffer (90 mM Tris-borate, $2 \mathrm{mM}$ EDTA) followed by staining with ethidium bromide $(0.5 \mu \mathrm{g} / \mathrm{ml})$. DNA fragments were visualized with a UV transilluminator, photographed with an IS-1000 digital imaging system (Alpha Innotech Corp., CA), and printed using a Seikosha VP-1500 II printer. DNA molecular weight markers (Fermentas) were used to determine the size of the amplified fragments.

\section{RESULTS}

Amplifiability of total RNA extracts. RubiscoL and/or MDH primer pairs amplified fragments of the expected size to clearly detectable amounts in essentially all total RNA extracts. Only one extract was nonamplifiable and thus discarded, and the remaining 419 extracts could be reliably tested for the chosen grapevine viruses.

Virus detection. $\mathrm{RSPaV}$ was detected in most extracts from RSPaV-infected plants (Table 2). Gel electrophoretic analysis showed fragments with sizes expected for amplification on Rubisco RNA or DNA (171 bp) and RSPaV RNA (355 bp) (data not shown) or MDH RNA (196 bp) and RSPaV RNA (355 bp), and larger fragments which represent MDH sequence amplified on DNA present in the extracts (14) (Fig. 1).

$\mathrm{RSPaV}$ could be detected at every stage in the spring; however, the virus was not detected in all spring samples. It was also generally detected in summer tissues except in buds collected from green canes. All seeds, untreated and bleach-treated, and dormant cane tissue contained detectable amounts of RSPaV. When three dormant buds per plant were tested individually, all three tested RSPaV-positive for all but one plant, for which two buds were positive (Table 3 ).

No plant extracts tested positive for Arabis mosaic virus (ArMV), GVA, or Grapevine virus $B(\mathrm{GVB})$.

Table 2. One-tube reverse transcription-polymerase chain reaction (RT-PCR) detection of Rupestris stem pitting associated virus (RSPaV) in samples collected at different times of the year from RSPaV-infected field-grown Vitis vinifera varieties and rootstocks

\begin{tabular}{|c|c|c|c|c|c|c|c|c|}
\hline \multirow[b]{3}{*}{ Variety } & \multicolumn{3}{|c|}{ Spring } & & & & \multirow[b]{3}{*}{$\underline{\text { Fall }}$} & \multirow{3}{*}{$\begin{array}{c}\text { Winter } \\
\text { Dormant } \\
\text { canes }\end{array}$} \\
\hline & \multirow{2}{*}{$\begin{array}{c}\text { Opening bud } \\
\text { to leaf } \\
\text { emergence }\end{array}$} & \multirow{2}{*}{$\begin{array}{c}\text { 2-3 leaves unfolded } \\
\text { to inflorescences } \\
\text { visible }\end{array}$} & \multirow{2}{*}{$\begin{array}{c}\text { Inflorescences } \\
\text { separated to flowers } \\
\text { separated }\end{array}$} & \multicolumn{3}{|c|}{ Summer } & & \\
\hline & & & & $\begin{array}{c}\text { Shoot } \\
\text { tips }\end{array}$ & $\begin{array}{c}\text { Buds from } \\
\text { woody canes }\end{array}$ & $\begin{array}{l}\text { Buds from } \\
\text { green canes }\end{array}$ & & \\
\hline Cabernet Franc & $1 / 1^{\mathrm{a}}$ & $3 / 3$ & $8 / 8$ & $6 / 6$ & $5 / 6$ & $5 / 6$ & $6 / 6$ & $6 / 6$ \\
\hline Chardonnay & $6 / 6$ & $25 / 25$ & $9 / 10$ & $5 / 8$ & $6 / 6$ & $4 / 6$ & $6 / 6$ & $6 / 6$ \\
\hline Gamay & & $8 / 8$ & & $6 / 6$ & $6 / 6$ & $6 / 6$ & $6 / 6$ & $6 / 6$ \\
\hline Merlot & $4 / 4$ & $7 / 7$ & $6 / 6$ & $6 / 6$ & $6 / 6$ & $2 / 6$ & $6 / 6$ & $6 / 6$ \\
\hline Pinot Noir & & $7 / 7$ & $3 / 3$ & $6 / 6$ & $6 / 6$ & $6 / 6$ & $6 / 6$ & $6 / 6$ \\
\hline Riesling & $2 / 2$ & $10 / 11$ & $2 / 5$ & $6 / 6$ & $6 / 6$ & $4 / 6$ & $6 / 6$ & $6 / 6$ \\
\hline Sauvignon Blanc & $3 / 3$ & $10 / 10$ & & $5 / 5$ & $6 / 6$ & $6 / 6$ & $6 / 6$ & $6 / 6$ \\
\hline Riparia & & $4 / 4$ & $6 / 6$ & $4 / 4$ & $4 / 4$ & $2 / 4$ & & $4 / 4$ \\
\hline 3309 & & $4 / 4$ & $8 / 8$ & $6 / 6$ & $6 / 6$ & $3 / 6$ & & $6 / 6$ \\
\hline Total & $16 / 16$ & $78 / 79$ & $42 / 46$ & $50 / 53$ & $51 / 52$ & $38 / 52$ & $42 / 42$ & $52 / 52$ \\
\hline
\end{tabular}

${ }^{a} \mathrm{RSPaV}$ positive samples/total number of samples; blank spaces represent no sample tested. 


\section{DISCUSSION}

The amplification of the internal controls to easily detectable amounts shows that this method for extracting total RNA is effective at reducing inhibitors in all grapevine tissues and at all times of the year, allowing our extracts to be amplified and tested for the presence of virus. A negative result would thus indicate that the amount of virus in the sample is low or nil.

$\mathrm{RSPaV}$ has been characterized only recently $(10,22)$ and there are no reports on the distribution of this virus within infected plants at different times of the year. Our results indicate that $\mathrm{RSPaV}$ is present in nearly all tissues of infected plants in amounts high enough for detection by the RT-PCR procedure employed. RSPaV was

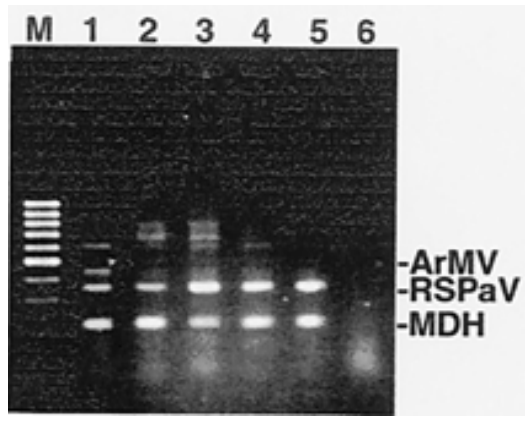

Fig. 1. Agarose gel analysis of multiplex reverse transcription-polymerase chain reaction (RT-PCR) assays with the primers for malate dehydrogenase (MDH), Rupestris stem pitting associated virus (RSPaV), and Arabis mosaic virus (ArMV) on total RNA extracts from: lanes 1 (positive control), 4, and 5, dormant cane; lane 2, bud from woody cane; lane 3 , seed; and lane 6, water (control). Lane M, molecular weight marker. Lanes with RSPaVnegative extracts are not shown. not detected in many of the buds collected in the summer from green canes, but it was detected in buds from woody canes collected at the same time. We suspect that since the buds on green canes are still young, the virus had not yet multiplied in them and thus the titer was too low to detect. There were no differences in $\mathrm{RSPaV}$ detection among the seven surveyed varieties or rootstocks 3309 and Riparia.

The fact that we did not have any problems finding RSPaV-infected vines in the Niagara region supports the claim that $\mathrm{RSPaV}$ is widespread (2,9). Since RSPaV can cause RSP symptoms if present in combination with another virus, we also tested for the presence of ArMV, GVB, and in particular GVA in cane samples, which were shown to be a reliable source for their detection (14). None of these viruses were detected.

The finding that all seeds tested positive for RSPaV, even after bleach treatment, suggests that virus is present inside the seed, even though RSPaV is not known to be seedborne (22). This has negligible importance for the industry since propagation of grapevines is via grafting.

Once grapevines become infected, $\mathrm{RSPaV}$ cannot be cured in the field. Control of the virus thus depends on the ability to detect and eliminate infected plants from nursery material, propagation stock, and imported material. For this to be successful, the most efficient sampling strategy to deal with fluctuations in virus titer and uneven distribution of virus within the plant has to be applied. Our results show that RT-PCR on dormant and actively growing tissue, but not on buds from green canes collected in the summer, can provide reliable data. Dormant canes must first be ground into shavings before the nucleic acids can be extracted. Fortunately, this time-consuming task can be avoided by using dormant buds instead. We suggest using at least three samples to account for the uneven distribution of virus within a plant.

\section{ACKNOWLEDGMENTS}

We thank John Paroschy, Chateau des Charmes Wines, for assistance with collecting grapevine samples. This work was supported by Chateau des Charmes Wines Limited with a NRC-IRAP grant.

\section{LITERATURE CITED}

1. Baggiolini, M. 1952. Les stades reperes dans le developpement annuel de la vigne et leur utilisation pratique. Rev. Rom. Agric. Vitic. Arboric. 8:4-6.

2. Bonfiglioli, R. G., Habili, N., Green, M., Schliefert, L. F., and Symons, R. H. 1998. The hidden problem - Rugose wood associated viruses in Australian viticulture. Aust. Grapegrower Winemaker 420:9-13.

3. Engelbrecht, D. J., and Kasdorf, G. G. F. 1990. Transmission of grapevine leafroll disease and associated closteroviruses by the vine mealybug, Planococcus ficus. Phytophylactica 22:341-346.

4. Green, M. J., Thompson, D. A., and MacKenzie, D. J. 1999. Easy and efficient DNA extraction from woody plants for the detection of phytoplasmas by polymerase chain reaction. Plant Dis. 83:482-485.

5. Krake, L. R., Steele Scott, N., Rezaian, M. A., and Taylor, R. H. 1999. Graft-transmitted Diseases of Grapevines. CSIRO Publishing, Collingwood, Australia. pp. 45-52.

6. MacKenzie, D. J. 1997. A standard protocol for the detection of viruses and viroids using a reverse transcription-polymerase chain reaction technique. Document CPHBT-RTPCR1.00. Canadian Food Inspection Agency.

7. MacKenzie, D. J., McLean, M. A., Mukerji, S., and Green, M. 1997. Improved RNA extraction from woody plants for the detection of viral pathogens by reverse transcriptionpolymerase chain reaction. Plant Dis. 81:222226.

Table 3. Distribution of Rupestris stem pitting associated virus (RSPaV) in individual infected grapevines in which at least one sample tested negative by one-tube reverse transcription-polymerase chain reaction (RT-PCR)

\begin{tabular}{|c|c|c|c|c|c|c|c|c|c|c|c|c|c|c|c|}
\hline \multirow[b]{4}{*}{ Variety } & \multicolumn{6}{|c|}{ Spring } & & & & & & & & & \\
\hline & \multirow{2}{*}{\multicolumn{2}{|c|}{$\begin{array}{l}\text { Opening bud } \\
\text { to leaf emer- } \\
\text { gence }\end{array}$}} & \multirow{2}{*}{\multicolumn{2}{|c|}{$\begin{array}{c}\text { 2-3 leaves unfolded } \\
\text { to inflorescences } \\
\text { visible } \\
\end{array}$}} & \multirow{2}{*}{\multicolumn{2}{|c|}{$\begin{array}{l}\text { Inflorescences } \\
\text { separated to flow- } \\
\text { ers separated }\end{array}$}} & \multicolumn{4}{|c|}{ Summer } & \multirow{3}{*}{$\begin{array}{c}\text { Fall } \\
\text { Seeds }\end{array}$} & \multicolumn{4}{|c|}{ Winter } \\
\hline & & & & & & & \multicolumn{2}{|c|}{$\begin{array}{c}\text { Shoot } \\
\text { tips }\end{array}$} & \multirow{2}{*}{$\begin{array}{l}\text { Buds from } \\
\text { woody } \\
\text { canes }\end{array}$} & \multirow{2}{*}{$\begin{array}{l}\text { Buds from } \\
\text { green } \\
\text { canes }\end{array}$} & & \multirow{2}{*}{$\begin{array}{c}\text { Dormant } \\
\text { canes }\end{array}$} & \multicolumn{3}{|c|}{$\begin{array}{c}\text { Dormant } \\
\text { buds }\end{array}$} \\
\hline & $\mathbf{1}^{\mathrm{a}}$ & 2 & 1 & 2 & 1 & 2 & 1 & 2 & & & & & 1 & 2 & 3 \\
\hline Chardonnay & & & + & + & - & + & + & & + & + & + & + & + & + & $+\mathrm{F}^{\mathrm{b}}$ \\
\hline Chardonnay & & & + & + & & & - & + & + & - & + & + & + & + & + \\
\hline Chardonnay & & & + & + & & & - & - & + & - & + & + & & & \\
\hline Riesling & + & & + & & + & - & + & & & + & + & + & + & + & + \\
\hline Riesling & & & - & + & + & - & + & & + & + & + & + & & & \\
\hline Riesling & & & + & & & & + & & + & - & + & + & + & + & $+\mathrm{F}$ \\
\hline Riesling & & & + & & & & + & & + & - & + & + & & & \\
\hline Merlot & + & & + & & & & + & & + & - & + & + & + & + & + \\
\hline Merlot & & & + & & & & + & & + & - & + & + & & & \\
\hline Merlot & & & + & & & & + & & + & - & + & + & & & \\
\hline Merlot & + & + & & & + & + & + & & + & - & + & + & + & + & + \\
\hline $\begin{array}{l}\text { Cabernet } \\
\text { Franc }\end{array}$ & + & & + & & + & + & + & & - & - & + & + & + & $+\mathrm{F}$ & - \\
\hline Riparia & & & & & & & + & & + & - & & + & + & + & + \\
\hline Riparia & & & & & + & + & + & & + & - & & + & & & \\
\hline 3309 & & & & & + & & + & & + & - & & + & & & \\
\hline 3309 & & & + & & + & & + & & + & - & & + & + & + & + \\
\hline 3309 & & & + & & + & & + & & + & - & & + & & & \\
\hline
\end{tabular}

a 1,2 , and 3 indicate different samples from the same vine.

${ }^{\mathrm{b}} \mathrm{F}$ = faint band; blank spaces represent no sample tested. 
8. Martelli, G. P. 1993. Rugose Wood Complex. Graft-transmissible Diseases of Grapevines, Handbook for Detection and Diagnosis. G. P. Martelli, ed. Food and Agriculture Organization of the United Nations, Rome, Italy. pp. 45-54

9. Meng, B., Johnson, R., Peressini, S., Forsline, P. L., and Gonsalves, D. 1999. Rupestris stem pitting associated virus- 1 is consistently detected in grapevines that are infected with rupestris stem pitting. Eur. J. Plant Pathol. 105:191-199.

10. Meng, B., Pang, S.-Z., Forsline, P. L., McPherson, J. R., and Gonsalves, D. 1998. Nucleotide sequence and genome structure of grapevine rupestris stem pitting associated virus-1 reveal similarities to apple stem pitting virus. J. Gen. Virol. 79:2059-2069.

11. Minafra, A., and Hadidi, A. 1994. Sensitive detection of grapevine virus A, B, or leafroll associated III from viruliferous mealybugs and infected tissue by cDNA amplification. J. Virol. Methods 47:175-188.

12. Minafra, A., Hadidi, A., and Martelli, G. P. 1992. Detection of grapevine closterovirus A in infected grapevine tissue by reverse tran- scription-polymerase chain reaction. Vitis 31:221-227.

13. Monis, J., and Bestwick, R. H. 1996. Detection and localization of grapevine leafroll associated closteroviruses in greenhouse and tissue culture grown plants. Am. J. Enol. Vitic. 47:199-205.

14. Nassuth, A., Pollari, E., Helmeczy, K., Stewart, S., and Kofalvi, S. A. 2000. Improved RNA extraction and one-tube RT-PCR assay for simultaneous detection of control plant RNA plus several viruses in plant extracts. J. Virol. Methods 90:23-35.

15. Reynolds, A. G., Lanterman, W. S., and Wardle, D. A. 1997. Yield and berry composition of five Vitis cultivars as affected by rupestris stem pitting virus. Am. J. Enol. Vitic. 48:449-458.

16. Rezaian, M. A., and Krake, L. R. 1987. Nucleic acid extraction and virus detection in grapevine. J. Virol. Methods 17:277-285.

17. Rowhani, A., Chay, C., Golino, D. A., and Falk, B. W. 1993. Development of a polymerase chain reaction technique for the detection of grapevine fanleaf virus in grapevine tissue. Phytopathology 83:749-753.
18. Rowhani, A., Maningas, M. A., Lile, L. S., Daubert, S. D., and Golino, D. A. 1995. Development of a detection system for viruses of woody plants based on PCR analysis of immobilized virions. Phytopathology 85:347352.

19. Rowhani, A., Uyemoto, J. K., and Golino, D A. 1997. A comparison between serological and biological assays in detecting grapevine leafroll associated viruses. Plant Dis. 81:799 801.

20. Rowhani, A., Walker, M. A., and Rokni, S. 1992. Sampling strategies for the detection of grapevine fanleaf virus and the grapevine strain of tomato ringspot virus. Vitis 31:35-44.

21. Staub, U., Polivka, H., and Gross, H. J. 1995 Two rapid microscale procedures for isolation of total RNA from leaves rich in polyphenols and polysaccharides: Application for sensitive detection of grapevine viroids. J. Virol. Methods 52:209-218.

22. Zhang, Y.-P., Uyemoto, J. K., Golino, D. A., and Rowhani, A. 1998. Nucleotide sequence and RT-PCR detection of a virus associated with grapevine rupestris stem-pitting disease. Phytopathology 88:1231-1237. 